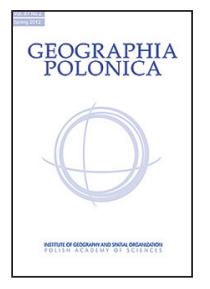

\title{
SPATIAL MODELLING OF AVALANCHES BY APPLICATION OF GIS ON SELECTED SLOPES OF THE WESTERN TATRA MTS. AND BELIANSKE TATRA MTS., SLOVAKIA
}

\author{
Martin Boltižiar ${ }^{1,2}$ - Marek Biskupič ${ }^{3,4}$ - Ivan Barka \\ ${ }^{1}$ Department of Geography \\ and Regional Development \\ Constantine the Philosopher University in Nitra \\ Trieda A. Hlinku 1, 94974 Nitra: Slovakia \\ e-mail: mboltiziar@ukf.sk \\ ${ }^{4}$ Institute for Environmental Studies \\ Charles University Prague \\ Ovocný trh 3-5, 11636 Prague 1: Czech Republic \\ ${ }^{2}$ Department of Geography \\ ${ }^{5}$ National Forest Department \\ T.G. Masaryka 22, 96092 Zvolen: Slovakia \\ e-mail:barka@nlcsk.org \\ J.E. Purkyně University in Ústí nad Labem \\ České mládeže 8, 40096 Ústi nad Labem: Czech Republic \\ ${ }^{3}$ Avalanche Prevention Center \\ Dr. J. Gašperíka 598, 03301 Liptovský Hrádok: Slovakia \\ e-mail: avalanches@hzs.sk
}

\begin{abstract}
The avalanches represent a significant and very dynamic process within the Tatra high-mountain landscape. Undoubtedly avalanche run-out distances play a key role in land use planning within avalanche prone areas. The Žiarska valley and Predné Med'odoly valley are considered as one of the most avalanche prone valleys in Tatra Mts. This environment represents an excellent opportunity for studying and modelling extreme avalanche run-outs. Primarily avalanche release zones were estimated by using an existing model proposed by Hreško (1998). This model was modified and calibrated for both valleys. The alpha-beta regression model developed in Norway has been used to estimate avalanche run-outs. Data processing and model calibration have been elaborated in GIS environment. Avenue script for ArcGIS was written to perform automated runout estimation based on alpha-beta regression model. Model managed to estimate run-outs on some slopes while it failed to model run-ups. Finally the results were visualized by creating the fly-through simulations and $3 \mathrm{D}$ views. Comparison between model calculation and avalanche cadastre showed correlation.
\end{abstract}

\section{Key words}

snow avalanche $\cdot$ GIS • run-out modelling • Western Tatra Mountains • Belianske Tatra Mountains 


\section{Introduction}

Over the course of several decades, the estimation of avalanche run-outs has been carried out in some countries within Europe and North America based on topographical parameters. Early attempts were made in USA (Bovis \& Mears 1976) and Norway (Lied \& Bakkehøi 1980). Since then the so called alpha-beta regression model (Lied \& Bakkehøi 1980) has been introduced in many countries and mountain ranges in the world (Fujisawa et al. 1993; Lied et al. 1995; Furdada \& Vilaplana 1998; Johannesson 1998; Barka 2003; Jones \& Jamieson 2004; Delparte 2008). Later on, with the development of computers and geoinformatics and their application for natural hazard zoning, GIS has been widely adopted. Terrain models (Toppe 1987) and GIS have been used to estimate the probable avalanche release zones (Hreško 1998; Maggioni \& Gruber 2003), model avalanche run-outs (Barka 2003; Delparte 2008) or assess the protective function of forest against avalanches (Sitko 2008; Bebi et al. 2001).

Four thousand avalanche paths are registered within five Slovak mountain ranges. Several hundred of these avalanche tracks cross roads, hiking trails and places often frequented by winter travellers and backcountry skiers. Avalanches have been observed during the last 50 years and their findings have been documented either in written form or drawn into an avalanche cadastre maintained by the Slovak Centre for Avalanche Prevention (SCAP). Several disastrous avalanches with extreme run-outs have occurred in the last 15 years and most of them have gone beyond the borders of well-known avalanche paths.

So far several projects dealing with the estimation of probable avalanche trigger zones using GIS have been developed in Slovakia (Hreško 1998; Hreško \& Bugár 1999; Hreško \& Boltižiar 2001; Barka 2003; Barka \& Rybár 2003; Kohút 2005; Boltižiar 2007; Sitko 2008) and also in Poland (Raczkowska et al. 2013; Rojan et al. 2013; Lempa et al. 2014). Most of them were carried out as part of research in local universities or institutes. The aim of this work is to use GIS techniques to estimate probable avalanche trigger zones and model run-outs on selected slopes. A simple equation model (Hreško 1998) for release zones is developed and used to automate the mapping of release zones in GIS. The model calibration has been based on data from the avalanche database maintained by SCAP. The avalanche path model uses a statistical regression model described by Lied and Bakkehøi (Lied \& Bakkehøi 1980) and is implemented into GIS by script written in Avenue programming language. Despite this, the model failed to accurately represent run-ups and curved channeled paths; it has functioned well with linear paths which run straight down slopes.

\section{Research area}

The Ziarska valley is situated in the Western Tatra Mts. and the Predne Metodoly valley is situated in the Belianske Tatra Mts. (Fig. 1). Due to their overall geomorphological character both valleys have very similar conditions for the formation of avalanches. From all the valleys in Slovakia's high mountains, they have the greatest topographic suitability for the formation of avalanches, especially in terms of size and frequency. The decisive factor is the overall morphology of avalanche gullies, especially the length and position of the cut-off zone, size of catchment area, length and slope of avalanche paths and vegetation conditions. According to the SCAP avalanche cadastre the length of avalanche paths is approximately $500-2000 \mathrm{~m}$ and height difference is $300-950 \mathrm{~m}$. These mountains provide particularly favourable conditions due to the lowering of the upper forest boundary and destruction of the dwarf-pine zone because of very long term extensive use of these areas for grazing sheep and cattle. On the longest and steepest section of the avalanche path, i.e. from the cut-off zone to the upper forest boundary, avalanches 


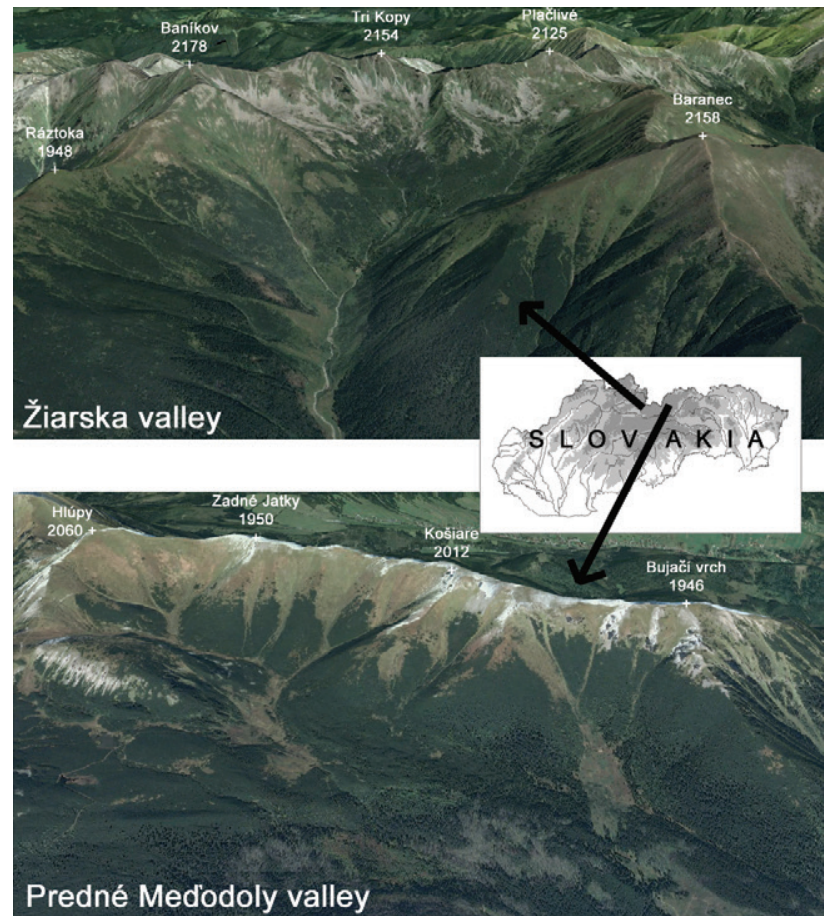

Figure 1. Research areas: Žiarska valley in Western Tatra Mts. and Predné Med’odoly valley in Belianske Tatra Mts.

Source: Orthophotos: @ Google Earth, 2014

grow not only in size, but especially in dynamic force. Their dynamic effects cause a clear cut to be produced right through the current forest area down to the bottom of the valleys, which shows not only their occurrence but also their destructive effects (Kňazovický 1967). The effects of avalanches were continuously monitored during the field surveys conducted during which photographic documentation was produced.

\section{Methods}

\section{Statistical analyses of the avalanche database: SLPDB}

The avalanche database contains information on avalanches that have occurred within the territory of Slovakia. The database consists of information on release zones (elevation, exposition, aspect, type of snow etc.), transport zones (shape, topographic parameters), deposition zones (shape, height, type, etc.), casualties and damage (number of people involved and injured, deceased, forest damage). The first record dates back to 1937. For the purpose of identifying release zones, relevant information (aspect and elevation of release zones) has been extracted from the database. Based on these parameters a model for avalanche trigger zones has been calibrated.

\section{Data sources and pre-processing}

The accuracy of the model results is dependent on the accuracy of data inputs. Therefore relative high accuracy of data inputs is required. Both models are based on topographical factors which require an accurate digital elevation model (DEM). Contours at $5 \mathrm{~m}$ intervals were used as a base for creating a DEM. For the Žiarska valley these 
were scanned from "The Base Map of Slovak Republic" at a scale 1:10,000 and those for the Predné Med'odoly valley were also generated by photogrammetric methods (Eurosenses s.r.o., Bratislava, SK). Consequently contour lines were vectorised and the DEM was computed using the spline function with tension (Mitášová \& Hofierka 1993). Because of the presence of artificial undulations in the DEM (profile curvatures varied from concave to convex around contours), DEM preprocessing was performed. Random points with the elevation attribute were extracted from the DEM. Points from the valley bottom contours (in strips $20 \mathrm{~m}$ wide on each side of thalwegs) were added to random points. As a result new elevation data points were created. Compared to the general fill method, this method of DEM creation prevents the generation of depressions in the valleys. It can be argued that there are more accurate ways of creating digital elevation models e.g. digital photogrammetry, aerial or terrestrial laser scanning or geodetic survey, but these methods are much more costly and time consuming. The land cover layer obtained by analysing the large scale vegetation maps $(1: 10,000)$ and aerial imagery were other important data inputs for estimating terrain roughness.

\section{Model of probable avalanche release zones}

An avalanche trigger or release zone can be described as an area with certain topographical features which allow deposition of snow masses. These snow masses tend to release as a snow avalanche under certain conditions. Hreško (1998) proposed a simple equation model for estimating avalanche release zones. The equation and model factors were modified according to the results of statistical analysis of the avalanche database. This step was done to calibrate real avalanche situations with the proposed model.

Table 1. Factors used to estimate trigger zones

\begin{tabular}{|c|c|c|c|c|c|}
\hline $\begin{array}{l}\text { Elevation } \\
\text { [m a.s.l.] }\end{array}$ & $\begin{array}{l}\text { Elevation } \\
\text { factor }[A /]\end{array}$ & $\begin{array}{c}\text { Plan } \\
\text { curvature }\end{array}$ & $\begin{array}{l}\text { Curvature } \\
\text { factor }[F y]\end{array}$ & $\begin{array}{c}\text { Profile } \\
\text { curvature }\end{array}$ & $\begin{array}{l}\text { Curvature } \\
\text { factor }[\mathrm{Fx}]\end{array}$ \\
\hline $\begin{array}{l}1200-1450 \\
1450-1700 \\
1700-1950 \\
1950-2200\end{array}$ & $\begin{array}{l}0.1 \\
1.0 \\
2.0 \\
0.5\end{array}$ & $\begin{array}{c}-4.0-(-0.2) \\
-0.2-0.2 \\
0.2-0.5 \\
0.5-4.0\end{array}$ & $\begin{array}{l}1.0 \\
1.0 \\
1.0 \\
0.5\end{array}$ & $\begin{array}{c}4.0-0.2 \\
0.2-(-0.2) \\
-0.2-(-0.5) \\
-0.5-(-4.0)\end{array}$ & $\begin{array}{l}1.0 \\
1.0 \\
1.0 \\
0.5\end{array}$ \\
\hline \multicolumn{4}{|c|}{ Cover type } & \multicolumn{2}{|c|}{ Roughness factor $[R g]$} \\
\hline \multicolumn{4}{|c|}{$\begin{array}{l}\text { Forest (coniferous, deciduous, mixed) } \\
\text { Open forest with dwarf-pine, rough stony debris and slope covered by lesser } \\
\text { blocks } \\
\text { Deciduous shrub wood } \\
\text { Open forest } \\
\text { Dwarf-pine and slope with exposures of parent rock jutting out less than } \\
50 \mathrm{~cm} \\
\text { Grass with sporadic dwarf-pine, and small size slope debris } \\
\text { Compact grass areas and rock plates }\end{array}$} & & \\
\hline $\begin{array}{c}\text { Slope } \\
{\left[{ }^{\circ}\right]}\end{array}$ & $\begin{array}{c}\text { Slope } \\
\text { factor }[S]\end{array}$ & Aspect & $\begin{array}{c}\text { Aspect } \\
\text { factor }[E x]\end{array}$ & & \\
\hline $\begin{array}{l}0^{\circ}-10^{\circ}, 70^{\circ}-90^{\circ} \\
10^{\circ}-19^{\circ}, 60^{\circ}-70^{\circ} \\
19^{\circ}-25^{\circ}, 55^{\circ}-60^{\circ} \\
25^{\circ}-30^{\circ}, 50^{\circ}-55^{\circ} \\
30^{\circ}-35^{\circ}, 45^{\circ}-50^{\circ} \\
35^{\circ}-45^{\circ}\end{array}$ & $\begin{array}{l}0.0 \\
0.4 \\
0.8 \\
1.2 \\
1.6 \\
2.0\end{array}$ & $\begin{array}{c} \\
N E \\
E \\
\text { SE } \\
\text { S } \\
\text { SW } \\
\text { W } \\
\text { NW }\end{array}$ & $\begin{array}{l}0.8 \\
0.5 \\
0.7 \\
1.5 \\
2.0 \\
1.0 \\
1.7 \\
0.4 \\
\end{array}$ & & \\
\hline
\end{tabular}




$$
A v=(A l+E x+F x+F y) \cdot S \cdot \operatorname{Rg}
$$

Where:

$A v$ - is a value estimating potential avalanche trigger zones,

Al - is the elevation factor,

Ex - is the aspect factor,

$F x$ - is the profile curvature factor,

Fy - is the plan curvature factor,

$S$ - is the slope inclination factor and

$\mathrm{Rg}$ - is the roughness factor.

The land cover layer and DEM are the two main data inputs for calculation of the model. Each of the factors ( $A l, E x, F x, F y, S, R g$ ) was classified according to Table 1 and the final grid layer $(A v)$ was calculated using map algebra. The classification was based on the data extracted from the avalanche database. According to the database, the lowest avalanche frequency is observed in the interval from $1200 \mathrm{~m}-1450 \mathrm{~m}$. Therefore this interval was given a score of 0.1 . The same was carried out for other factors (plan and profile curvature, land cover, etc). The complete methodology of the classification can be found in studies done by Hreško, Bárka and Rybár (Hreško 1998; Bárka \& Rybár 2003).

Final reclassification according to Table 2 resulted in a final grid layer which represents avalanche prone areas. Avalanche prone areas have higher values of Av.

Table 2. Final reclassification

\begin{tabular}{|c|l|}
\hline $\begin{array}{c}\text { Equation (1) } \\
\text { result Av }\end{array}$ & \multicolumn{1}{|c|}{$\begin{array}{c}\text { Avalanche } \\
\text { trigger hazard }\end{array}$} \\
\hline $\begin{array}{c}0.0-15.0 \\
15.0-22.5\end{array}$ & low \\
$22.5-30.0$ & medium \\
$30.0-36.0$ & high \\
\hline
\end{tabular}

ArcGIS was used to fully automate the estimation of probable trigger zones by using the model builder module (Fig. 2). For avalanche run out modelling based on this, zones reaching an Av value of at least 22.5 or more were selected. The final output was compared with the avalanche cadastre map, visually assessed, and imported into ArcScene to create 3D bird's eye views for the Žiarska valley (Fig. 6).

\section{Avalanche run out modelling}

For the purpose of this work a model developed in Norway by Lied and Bakkehøi was implemented into GIS. The model predicts a maximal avalanche run out using the terrain parameters of the avalanche chute. Avalanche dynamics are not taken into account. The authors based the model on analyses of hundreds of well-known avalanche chutes. They chose a reference point (the so called the $\beta$ point) with the angle $\beta$ defined as the average gradient of the avalanche path profile from the position where the slope decreases to $10^{\circ}$ to the trigger zone (Fig. 3 ).

The angle $\alpha$ is the angle sighting from the extreme run out position to the trigger zone. Least square regression analysis showed a correlation between the $\alpha$ and $\beta$ angle and that the relationship has the form of an equation (Lied \& Bakkehøi 1980).

$$
\alpha=C O+C 1 \beta
$$

The model was calibrated on a dataset of 44 avalanche paths from both valleys (30 from the Žiarska valley and 14 from the Predné Med'odoly valley) with well-known run-outs. With the assistance of the expert knowledge of avalanches of J. Peto from SCAP, maximum run outs were measured on the terrain using GPS. A survey of aerial imagery accompanied the fieldwork to increase the accuracy of measurements. The topographical parameters of each path were extracted in ArcGIS and linear regression analysis was performed using a statistical package NCSS. Acquired regression coefficients together with avalanche trigger zones (where $A v \geq 22.5$ ) served as the input parameters for script written in Avenue for ArcGIS. This script models avalanche movement as flowing water. It creates flowlines from certain points (avalanche trigger zones), then it finds $\beta$ points, calculates the $\beta$ angle, and following this it estimates the $\alpha$ angle 


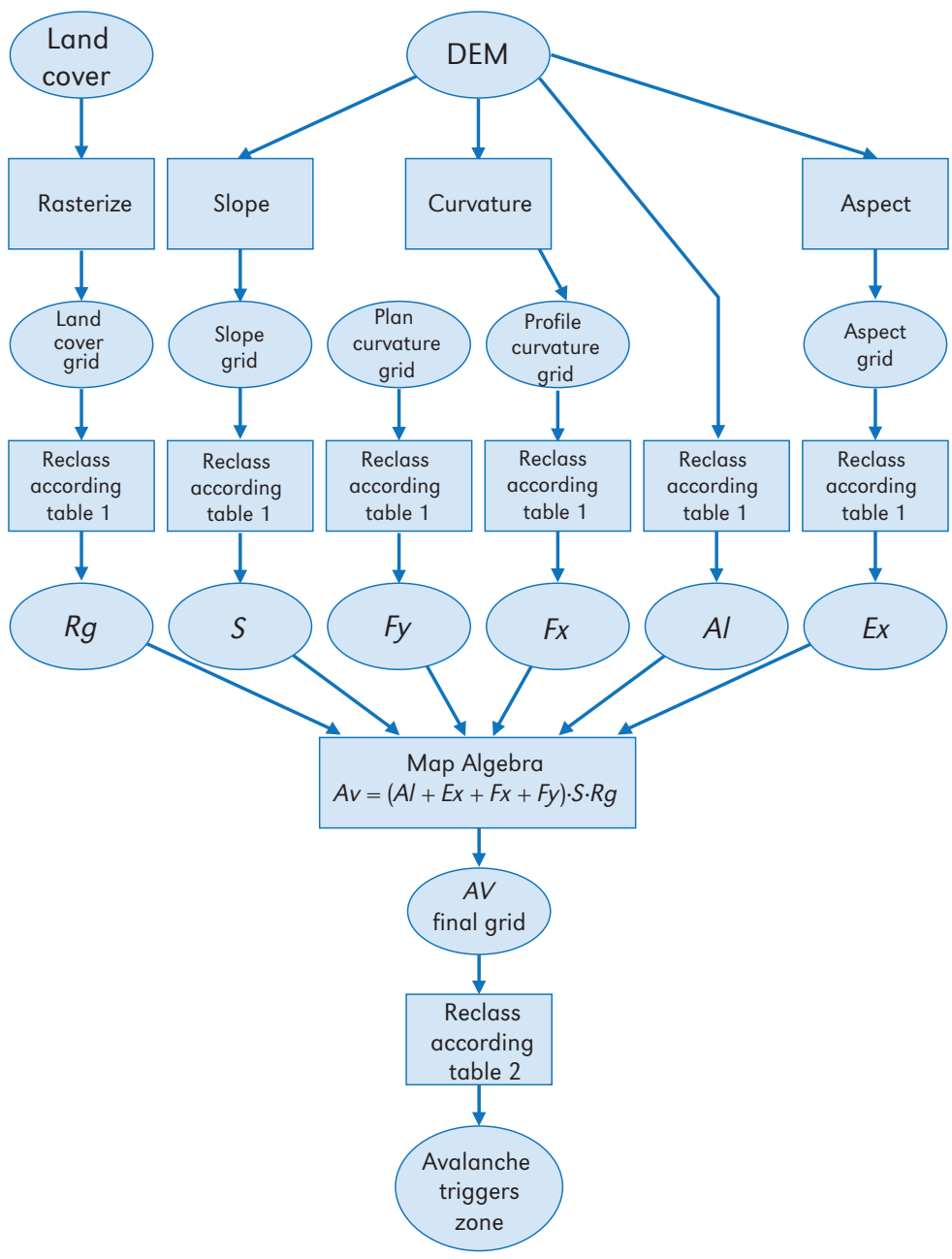

Figure 2. Workflow of the trigger zones estimation model

based on Equation 2. Later it estimates the point $\alpha$ and cuts the flow-line at this place. The script runs automatically and in addition to the input points, it needs DEM in the form of TIN. Because the avalanche movement is modelled as water, some problems are raised. At one point all the flowlines connected and continued as one flowline, which is the natural behaviour of water but not common in avalanches. This was solved by the channel network module in SAGA GIS. The module derives a channel network based on gridded digital elevation data and is enabled to keep all the separated flowlines in one flow simi- lar to the flow of avalanches. The proposed method enabled almost automated estimation of avalanche paths. Due to the lack of time and computer capacity the method was only used on selected slopes.

\section{Results}

Results from the model estimating probable avalanche paths correlate well with the avalanche cadastre map (Fig.6). It was expected that trigger zones estimated by the model will occur in the upper parts of historical avalanche paths. Due to forest succession 


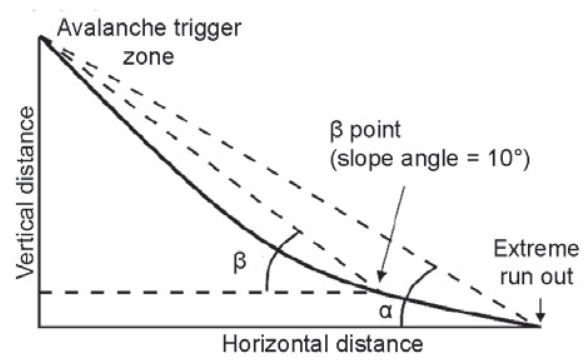

Figure 3. Topographical run-out model

$10 \%$ of the avalanche trigger areas are no longer avalanche prone. This is due to the growth of mature forest on such sites forming a perfect avalanche barrier. The up to date land cover layer used in the model influenced the result so that areas with lower avalanche triggering potential were properly estimated. Field investigation and aerial imagery inspection indicated significant forest succession in these places over the last 25 years. Due to this succession, avalanche activity was reduced to a minimum. Use of the up to date land cover maps and orthophotos as an input to the model resulted in the proper estimation of potential avalanche trigger hazards. The model revealed that in the Žiarska valley, $68 \%$ of the area studied falls into a zone with small avalanche trigger potential; 21\% with medium; $10 \%$ with high and $1 \%$ with very high avalanche trigger potential and in the Predné Med'odoly valley: $62 \%$ of the area studied falls into the zone with small avalanche trigger potential; $14 \%$ with medium; $14 \%$ with high and $10 \%$ with very high avalanche trigger potential (Fig. 4). Due to implementing the data from the avalanche database and the curvature factor, the estimated release zones reflect the nature of avalanche triggering (Fig. 7). Ridges were properly classified as places with minimal avalanche trigger potential (Fig. 5). On the other hand high or very high risk potential was given to the steep gullies and vast steep slopes covered with grass. This is one of the reasons why the Predné Med'odoly valley has more 'very high' avalanche release potential areas.

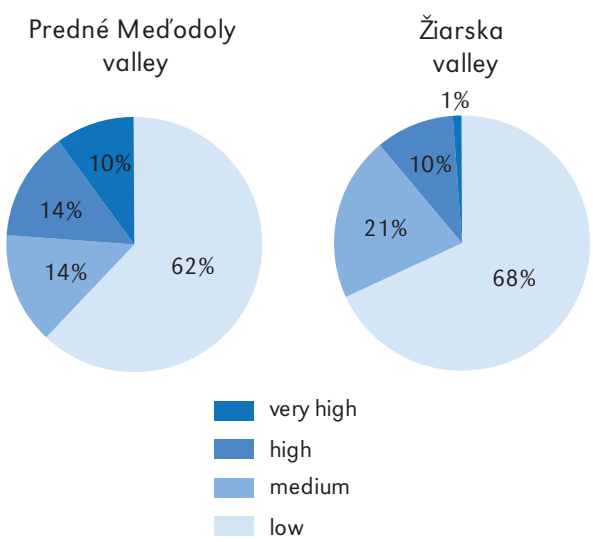

Figure 4. Comparison of avalanche release potential areas in \%

\section{Avalanche run-outs}

Use of scripting language (Avenue) in GIS allowed the implementation of statistical run out modelling in an automated manner. This was done on selected slopes. The final regression equation for the Western Tatra and Belianske Tatra Mts. is

$$
\alpha=0,91 ß-0,04^{\circ}
$$

The correlation coefficient for this regression is 0.95 , the coefficient of determination is 0.9 , and the standard error of the predicted $\alpha$ angle is 1.1. Figure 6 shows the final runouts on all the avalanche paths in both valleys. It can be stated that in this case the model outputs are in good agreement with the historical avalanche cadastral map. In some other cases the model failed to represent run-outs in a natural manner, e. g. runups and channelled curvy run-outs. Because the avalanche movement was approximated as water flow, circumstances occurred in narrow channels where all the flowlines gathered together and from a certain point they flowed together. This was partially solved by the channel module in SAGA. Unfortunately in some extremely curved channels satisfactory results were not obtained and different methods should be used for determining avalanche width. 

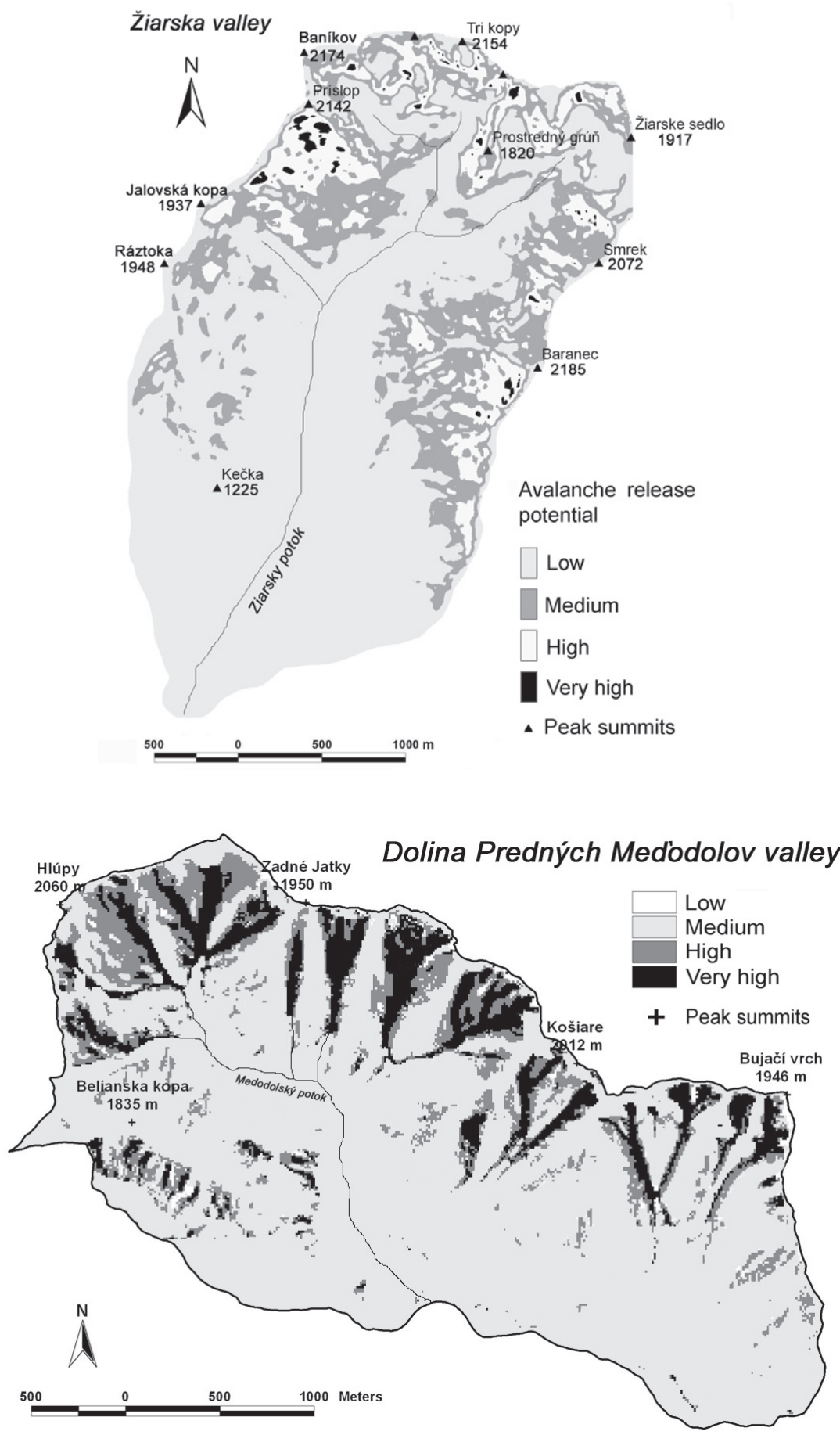

Figure 5. Avalanche release potential within the sites studied 

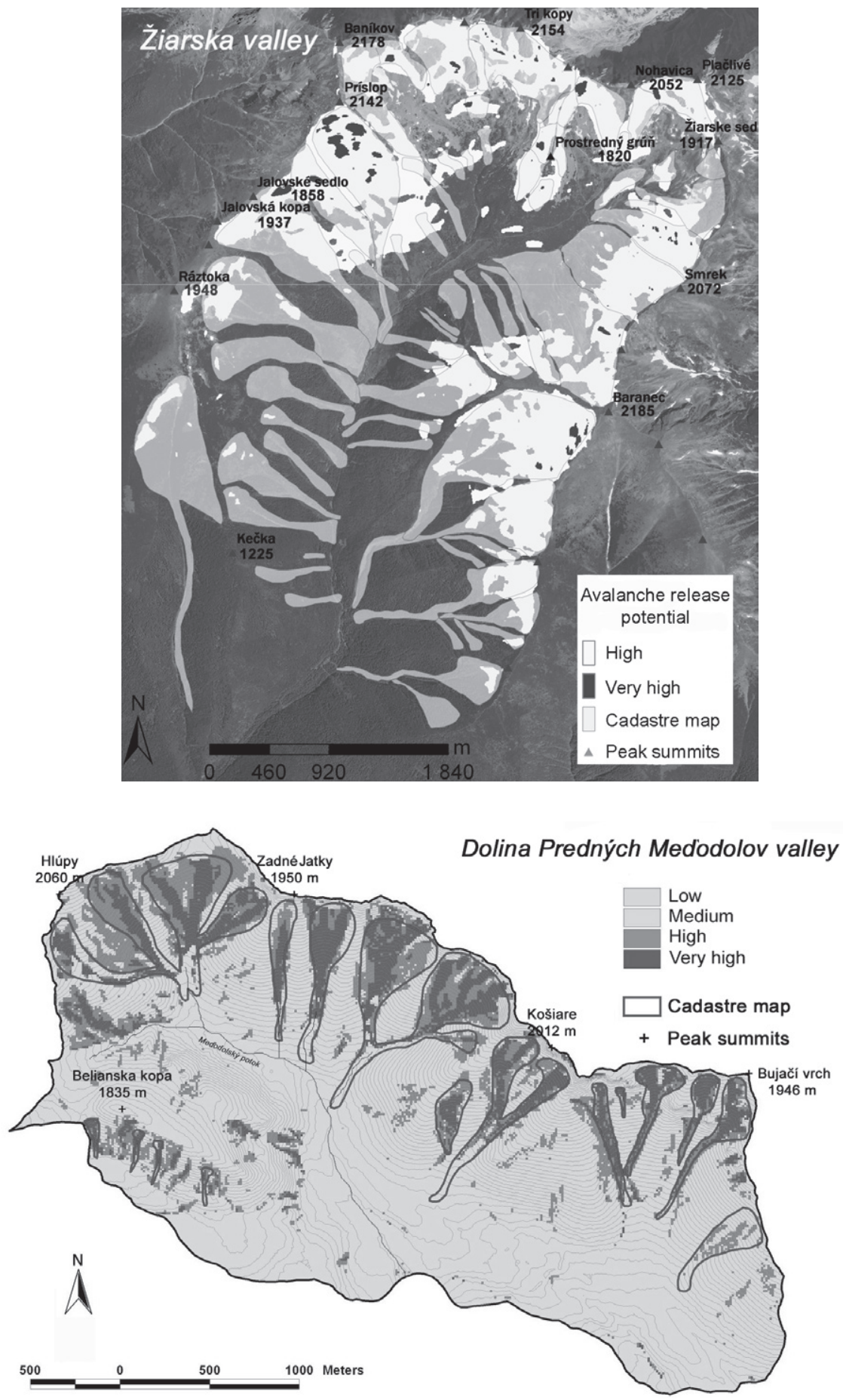

Figure 6. Avalanche release potential compared with the cadastre map 


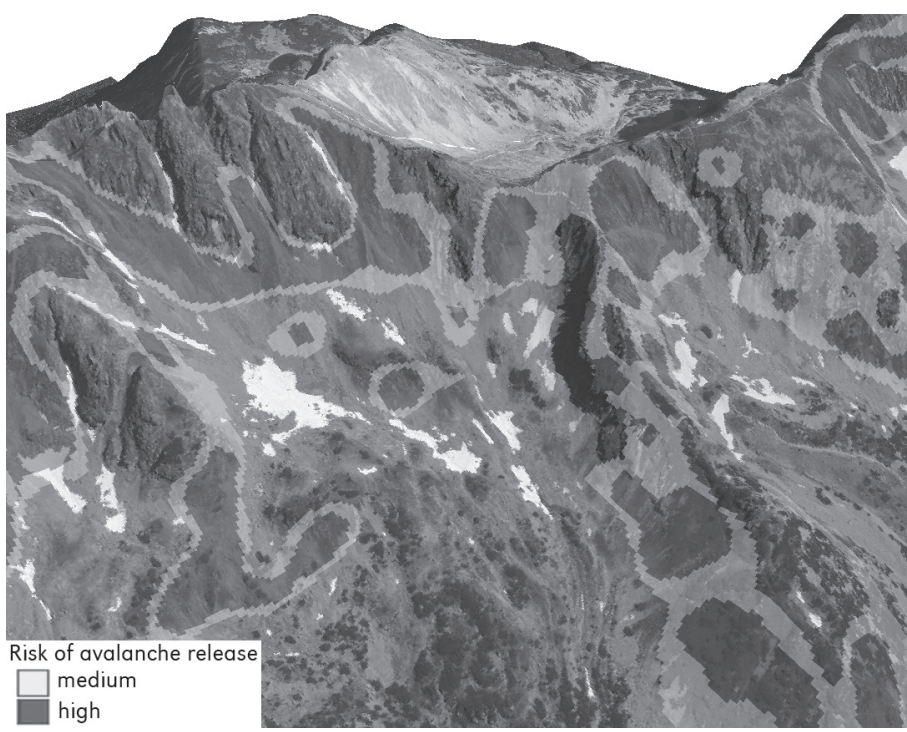

Figure 7. High and very high avalanche release potential in the Žiarska valley (3D view in ArcGIS)

\section{Conclusions}

A visual assessment of the avalanche trigger model shows agreement with the avalanche cadastre in some cases. The model did not estimate several trigger zones which were mainly located in the lower parts of the valleys. In total $91 \%$ of the pixels marked as avalanche prone areas fit in the area of the avalanche cadastre. In future, more detailed observations and the use of satellite imagery will be required to obtain data on avalanche prone locations. This can be explained by the succession undergone in these trigger zones. Field investigation proved that the trigger zones are naturally reforested and therefore avalanche activity is reduced. This conclusion is also supported by direct avalanche observations which did not report any avalanche for the last 15 years. It is crucial to use the most up to date data on land cover because only this can guarantee the proper estimation of the actual trigger areas. The release zones evolve in space and time according to the development of avalanche activity and forest succession.

The avalanche trigger model is easy to implement in the GIS environment. It is simple to calculate the model factors and, after several improvements, the model may be used in avalanche zoning. It will be interesting to see the future development of the model. In operational use the coupling of the model with on line meteorological data could help to improve the results and it could, in particular, enable one to estimate the actual trigger zones in real time depending on the weather situation. This would be a great aid to people travelling in avalanche prone areas.

The alpha-beta regression model implemented into GIS showed several discrepancies with the real behaviour of avalanches. In many cases it was not possible to find the beta reference point. This is caused by the relative steepness of the study region. Most of the avalanches do not reach the beta point and they terminate either on the steep valley bottom or the opposite slope. The model was devolved in Norway taking into account local topography which differs from topographies in the Western Tatra Mts. or Belianske Tatry Mts. It cannot be stated that the model doesn't work at all. It works, but just for specific slopes. The model is suitable for straight down sloping paths with no run-ups in the depositional area. 
The method developed for avalanche zoning showed that many improvements will have to be done to use this method for land use planning. It is an advantage especially for avalanche zoning on small scales that models are implemented into GIS and can perform the simulations in an automated manner. After refinement and adjustment the method can be translated to other mountain areas. The proposed method of estimation of avalanche prone areas seems to be a good replacement of a method based entirely

\section{References}

BARKA I., 2003. Identification of snow avalanche trigger areas and avalanche paths by the GIS. Geomorphologia Slovaca, vol. 3, no. 2, pp. 60-63.

BARKA I., RYBÁR R., 2003. Identification of snow avalanche trigger areas using GIS. Ecology, vol. 22, suppl. 2, pp. 182-194.

Bebi P., Kienast F., Schonenberger W., 2001. Assessing structures in mountain forests as a basis for investigating the forests' dynamics and protective function. Forest Ecology and Management, vol. 145, no. 1-2, pp. 3-14.

BoltižIAR M., 2007. Structure of the Tatra high mountain (large scale mapping, analysis and evaluation of changes by application of remote sensing data). Nitra: Fakulta prírodných vied Univerzity Konštantína Filozofa, Ústav krajinnej ekológie SAV Bratislava, Pobočka Nitra, Slovenský národný komitét pre program UNESCO Človek a biosféra.

Bovis M., Mears A., 1976. Statistical prediction of snow avalanche run-out from terrain variables in Colorado. Arctic and Alpine Research, vol. 8, no. 1, pp. 115-120.

Delparte D., 2008. Avalanche terrain modeling in Glacier National Park, Canada. Calgary: University of Calgary [PhD thesis].

Fujisawa K., Tsunaki R., Kamilshi I., 1993. Estimating snow avalanche run out distances from topographic data. Annals of Glaciology, 18, pp. 239-244. on field observations. It saves time and brings more safety to the SCAP staff. On the other hand, avalanches are very difficult to predict and only relying on model outputs is not advisable. In some way or other, field observations will always be necessary.

Editors' note:

Unless otherwise stated, the sources of tables and figures are the authors', on the basis of their own research.

FurdadA G., VILAplana J.M., 1998. Statistical predication of maximum avalanche run-out distances from topographic data in the western Catalan Pyrenees (northeast Spain). Annals of Glaciology, 26, pp. 285-288.

HREŠKO J., 1998. Avalanche hazard of the Tatra high mountain landscape. Folia Geographica, 2, Prešov: Prešovská univerzita, pp. 348-352.

HRĚ̌Ko J., BOLtIŽIAR M., 2001. The influence of the morphodynamic processes to landscape structure in the high mountains (Tatra Mts.). Ekológia, vol. 20, suppl. 3, pp. 141-148.

HRĚ̌KO J., BugÁR G., 1999. Avalanche risk of the SE part of Belianske Tatra Mts [in:] T. Hrnčiarová, Z. Izakovičová (eds.), Krajinnoekologické plánovanie na prahu 3. Tisícročia, Bratislava: Ústav krajinnej ekológie SAV, pp. 268-269.

JOHANNESSON T., 1998. A topographical model for Icelandic avalanches. Reykjavik: Icelandic Meteorological Office Report Vi-G980003-UR03.

JONES A., JAMIESON B., 2004. Statistical avalanche runout estimation for short slopes in Canada. Annals of Glaciology, vol. 38, no. 1, pp. 363-372

KŇAZOVICKÝ L., 1967. Avalanches. Bratislava: Vydavatel'stvo SAV.

Конút F., 2005. Natural processes in high mountain landscape - Jalovecká valley. Nitra: University of Constantine the Philosopher [PhD thesis].

Lempa M., KaczKa R.J., RaczKowsKa Z., 2014. Rekonstrukcja aktywności lawin śnieżnych w Białym Żlebie (Tary Wysokie) na podstawie przyrostów rocznych świerka pospolitego (Picea abies L. Karst.). Studia i Materiały Centrum 
Edukacji Przyrodniczo-Leśnej, vol. 16, no. 3, pp. 105-112.

LIED K., BAKKEHOI S., 1980. Empirical calculation of snow-avalanche run-out distance based on topographic parameters. Journal of Glaciology, vol. 26, no. 94, pp. 165-177.

Lied K., Weiler C., Bakkehøı S., Hopf J., 1995. Calculation methods for avalanche run-out distance for the Austrian Alps [in:] F. Sivardière (ed.), The contribution of scientific research to safety with snow, ice and avalanche. Grenoble: Association nationale pour l'étude de la neige et des avalanches, ANENA, pp. 63-68.

Maggioni M., Gruber U., 2003. The influence of topographic parameters on avalanche release dimension and frequency. Cold Regions Science and Technology, vol. 37, no. 3, pp. 407-419.

Mitášová H., Hofierka J., 1993. Interpolation by regularized spline with tension: II. Application to terrain modeling and surface geometry analysis. Mathematical Geology, vol. 25, no. 6, pp. 657-667.

RąCZKOWska Z., DŁugosz M., KaczKa R., KalaFARSKI M., Rojan E., 2013. Geomorphological aspects of snow avalanche activity in the Polish Tatras. Geomorphologia Slovaca et Bohemica, vol. 13, no. 1, pp. 67-68.
Raczkowska Z., Długosz M., Gadek B., Grabiec M., Kalafarski M., Rojan E., 2014. Environmental conditions, dynamic and multiproxy records of snow avalanches in the Tatra Mts [in:] IGU 2014 Book of Abstracts, Kraków: IGU, pp. 1.

Rojan E., Rączkowska Z., Kalafarski M., Długosz M., KaczKa R., Gądek B., 2013. Avalanches in relation to relief of the Tatra Mountains [in:] Geomorphology and Sustainability. Paris, 27-31 August 2013. 8th International Conference (AIG) on Geomorphology. Abstracts volume, p. 1066.

SitKo R., 2008. Identification, classification and assessment of forest function with the use of geoinformatics. Zvolen: Technical University [PhD thesis].

TOPPE R., 1987. Terrain models: A tool for natural hazard mapping [in:] B. Salm, H. Gubler (eds.), Avalanche formation, movements and effects (Proceedings of the Davos Symposium, September 1986), International Association of Hydrological Sciences (IAHS), no. 162, pp. 629-638.
(C) Martin Boltižiar • Marek Biskupič • Ivan Barka

(C) Geographia Polonica

(C) Institute of Geography and Spatial Organization

Polish Academy of Sciences • Warsaw • 2016
Article first received • October 2015 Article accepted • February 2016 